\title{
New Imperative of Corporate Value Creation in Face of the Challenges of Sustainable Development
}

\author{
Andrzej Jaki, Barbara Siuta-Tokarska
}

A B S T R A C T

Objective: The aim of the article is to present and exemplify the mechanisms of changes in defining and influencing the new imperative of corporate value creation. It is implied by the impact of the sustainable development concept.

Research Design \& Methods: The research focused on the concept of corporate value creation in the context of the challenges connected to sustainable development. In the article, both inductive and deductive ways of reasoning were adopted, which makes it possible to combine the results of the detailed research.

Findings: The publication indicates the emerging need for a change in the manner of perceiving and thinking about values - 'from grasping value for today - towards the value of the future.' This is related to the need to formulate the new imperative of corporate value creation.

Implications \& Recommendations: The reasonable profit concept can also be the basis for the formulation of the postulate of 'reasonable speed of corporate value creation.' Therefore, there is a need to redefine the existing imperative of corporate value creation and implement a new imperative based on the idea of the responsibility for the existence and long-term development of the enterprise.

Contribution \& Value Added: The result is the disclosure of the emergence of a hybrid concept of sustainable value-based management. The added value of this article is the proposal to create a new imperative of corporate value creation based on the foundation of the restitution of the idea of responsibility.

\begin{tabular}{ll}
\hline Article type: & $\begin{array}{l}\text { conceptual article } \\
\text { theory of development; sustainable development; corporate value cre- } \\
\text { Keywords: }\end{array}$ \\
JEL codes: & D8, L2, M2, Q5
\end{tabular}

\section{Suggested citation:}

Jaki, A., \& Siuta-Tokarska, B. (2019). New Imperative of Corporate Value Creation in Face of the Challenges of Sustainable Development. Entrepreneurial Business and Economics Review, 7(2), 63-81. https://doi.org/10.15678/EBER.2019.070204 


\section{INTRODUCTION}

In the source approach, sustainable development is understood as a process of transformations that is supposed to ensure that the needs of the present generation are met without compromising the developmental opportunities of future generations (by means of integrated activities with regard to the natural, social, and economic environments). The implementation of global-scale activities has its sources in the local space; these activities are manifested in practice in the effects of the functioning of business entities of different sizes (including very large, large, and small enterprises) in the context of natural, social, and economic capital, among others.

The activity of enterprises translates directly into the natural environmental, social, and economic systems in which they accomplish their goal. Therefore, sustainable development on the level of an enterprise means the broadly understood ecologisation of the operational processes with a simultaneous attempt to fulfill the expectations of possibly all stakeholders (including the financial expectations of the owners, the needs for the safety and stabilisation of the employees, and others). In the macro-economic dimension, it refers threefold (economically, socially, and ecologically) to the sustainable socio-economic development that is the foundation for the strand of economics called New Pragmatism (Kolodko, 2017).

Striving for the sustainable development of an enterprise has significantly influenced the conditionings that accompany the realisation of the basic financial goal, which is market value maximisation. The conclusions coming from both the implementation and use of the value-based management concept as well as the experiences of the latest global economic crisis related to the mentioned concept showed the need to expose the shared value creation as the fundamental goal of an enterprise on the one hand and the postulate for the evolution of the value-based management concept towards the new hybrid concept of sustainable value-based management on the other.

The aim of the article is to present and exemplify the mechanisms of changes in defining and influencing the imperative of corporate value creation implied by the impact of the sustainable development concept and a relative need for the coincidental treatment of the environmental, social, and economic conditionings of the management process.

The research problem posed by the authors of this publication does not solely concern the question of the observed effects of changes in the contemporary economy; i.e., the lack of sustainability between the three economic pillars (natural, social, and economic capital) is also connected with the search for their sources. The authors are of the opinion that the reason for this situation is the misunderstanding and lack of the actual implementation of some 'values' that may be regarded as superior in the socio-economic life of a person living at the turn of the 21st century. This lack of value implementation is manifested in the bitter taste of the so-called liquid modernity described by Bauman (2000) in the context of social philosophy. In this field, a type of research gap appears that has been identified as the previous lack of correlation between the concept of sustainable development and the concept of creating organisational values in the aspect of a new way of understanding the imperative of creating values.

The authors claim that the tendency to multiply the value of invested capital and the need for development should be sustainable and long-lasting, and it should be character- 
ised by the responsibility for the existence and future prosperity of the organisation. Moreover, the publication indicates the emerging need for a change in the manner of perceiving and thinking about values (environmental, social, and economic ones): 'from grasping value for today - towards the value of the future'.

The article is structured as follows. First, we present our research questions and methods, followed by a literature review and theory development. This chapter is divided into five sections. The first two sections present the concept of sustainable development and its connection with the category of value. The next two show the essence of the imperative of corporate value creation and the concept of value-based management; the need for changes in this concept are also indicated here. Finally, the last section presents the new concept of sustainable value-based management, followed by our conclusions.

\section{MATERIAL AND METHODS}

Presenting and exemplifying the mechanisms of changes in defining and influencing the imperative of corporate value creation (including striving to link the concept of value-based management with the concept of sustainable development) required the formulation of research questions that would specify the aim of the article. The research questions presented below were posed in connection with the above-mentioned obstacles and problems. To answer them, some theoretical and cognitive analyses were made that should, in turn, result in eliminating the above-mentioned research gap. The questions are as follows:

1. In what way is the concept of value reflected in the concept of sustainable development?

2. On what foundation should the imperative of value creation within the organisation activity be based?

How do we gain a consensus between the pragmatic expectations of investors concerning the maximisation of the economic capital value and the need for preserving moderation referring to the level of risk-taking by managers without treating the concept of value-based management as a kind of financial perpetuum mobile?

The needs related to achieving the aim of the article and providing answers to the formulated research questions constitute the criteria according to which the research methods were chosen. Taking into account the conceptual nature of the article, the analysis and critical evaluation of the book as well as the literature relating to the subject matter were used in the first place. In particular, this applies to key books in the field of development economics, philosophical, and economic value theory, sustainable development, value-based management, and the impact of the concept of social responsibility on shaping the development and value of the enterprise. The results of the conducted analysis became the basis for the synthesis. Current articles were also used that referred to the conditions, limitations, and effects of implementing both the concept of sustainable development and the concept of value-based management. The use of primarily deductive reasoning as well as inductive reasoning enabled us to formulate qualitative conclusions resulting from our literature review as well as the results of our own research and secondary research. Taking into account the pragmatic nature of the management science in the article, a normative approach based on formulating standards and recommendations for 
business practice was also used. This also highlights the application values of the article. As a result, it allowed us to answer the research questions (thus, the aim of the article).

\section{LITERATURE REVIEW AND THEORY DEVELOPMENT}

\section{Sustainable Development: Concept and Idea}

The paradigm of sustainable development that has been present in the environmental, social, and economic aspect of life for more than 30 years is indicated as a real fact, inscribing in and even co-shaping the current stage of the civilisational development of mankind (Egelston, 2013). The above-mentioned problems are part of the issues discussed within the frameworks of the economy of development ${ }^{1}$ concerning especially those theories that are regarded as second-generation theories. Within the research on economic changes in reference to those theories, the importance of the qualitative factors of a non-economic origin has been underlined ${ }^{2}$. Social goals is underlined and the good, both of an average man and especially social groups regarded as 'economically handicapped', constitutes a value with simultaneous bearing in mind to preserve the rules of economic effectiveness both in the micro and macro-economic dimension ${ }^{3}$. The theories of the economy of development may therefore be treated as the foundations for building the concept of sustainable development.

In their attempt to thoroughly and multidimensionally analyse the literature of the subject, the authors nevertheless decided not to present the historical analyses or the evolution of the views concerning the concepts of sustainable development and the tools measuring it, being aware of the fact that this topic has been fairly well-described in the subject literature and also taking bibliometric analyses into consideration (for instance,

\footnotetext{
${ }^{1}$ Among the doctrines of supporting the development, one can notice that these theories are both abundant and in many cases contradictory, which causes them to be perceived as not one consistent system on the required shape of an economic system. It is nevertheless possible to distinguish the following theories (Dobrescu, Hristache, \& lacob, 2012):

- the theory of economic growth comprising the post-Keyenist current (Robinson, Harrod, Domar, Kalm, Kaldor, or Bombach) and the neo-classical (the works of Meade, Solow, and Swan),

- economic development (especially Schumpeter), and

- the development of poorly economically developed countries (Bentham, Nurkse, Myrdal, Rostow, Rosenstein-Rodan, and Chenery).

2 The main problems of the theory of the economy of development of the first generation concentrate around the accumulation of capital as the preliminary and sufficient condition for development (assuming that some part of this capital must come from outside sources as some kind of external aid or foreign investment) Among these theories, it is worth enumerating the following:

- the 'big-push' theory by Rosenstein-Rodan (see Kreickeiemier \& Wrona, 2017),

- the theory of balanced growth by Nurkse (see Kattel, Kregel, \& Reinert, 2009),

- the strategy of economic development by Hirschman (see Ellerman, 2004),

- the theory of economic development with unlimited supplies of labour by Lewis (see Wang \& Piesse, 2009) or

- the stages of growth theory by Rostow (see Solivetti, 2005).

As far as the theories of the economy of development of the second generation are concerned, another approach can be observed among its representatives. They are institutionalists (Ayres, Veblen, Commons), structuralists (Prebisch), or the supporters of the school of dependencies (Singer, Preibisch). In these theories, the way in which the problem of development is perceived has changed, taking into consideration the areas being of a non-economic character (especially social issues).

${ }^{3}$ The suggested strategies in this respect are the strategy of basic needs and the strategy of fighting poverty, creating new places of work, domestic product redistribution, and grass-roots development.
} 
Pulgarín, Eklund, Garrote, \& Escalona-Fernández, 2015; Bettencourt \& Kaur, 2011; Cairns \& Martinet, 2014; Dahl, 2012). Instead, they try to present the essence of sustainable development in the context of the issues connected with creating values in organisations, showing the mechanisms of changes at the same time and presenting their own proposals connected with the discussed topics.

A good command of the subject literature also makes it possible for the authors to characterise sustainable development as a science by presenting the views of its main representatives, starting with the ones radically opting for social justice and preserving the natural environment (the supporters of Eco Socialism, socio economy, feminist economy, or the socalled deep economy) and finishing with those who are supporters of corpo-capitalism, as well as those whose efforts aim at creating capitalism with a human face (the supporters of making capitalism less green) or even apostates with Daly as their leader.

To sum up, one can claim that the implementation of the concept of sustainable development requires some kind of consensus between three ideological and political fields:

- ecologism connected with durability,

- a political system warranting social justice, and

- an economic system that ensures economic growth but without violating the fields proceeding it.

The authors of the publication are of the opinion that the layout (the position) of these three elements should be arranged in a suitable ranking. This issue is discussed later in this publication.

In spite of the lack of doubts in practical terms as for the need to implement the concept of sustainable development as well as the necessity of the co-awareness in its creation in theoretical terms, its full realisation is questioned (Borys, 2011). Some researchers who deal with the subject of the contemporary development of the world point to the permanence of changes and the omnipresent state of imbalance as a common phenomenon and even established in today's reality. They ask how we can talk about balance if the state of imbalance is a natural state. In this context, however, a question arises: is it really a natural state or only the one observed/occurring at the present stage of world development?

On the other hand, other researchers point to sustainable development as a well described paradigm that is not only a general idea or a vaguely defined one (e.g., Borowiecki \& Siuta-Tokarska, 2018; Olawumi \& Chan, 2018; Sinakou, Boeve-de Pauw, Goossens, \& Van Petegem, 2018). When comparing these two contradictory statements, it seems appropriate to look at self-regulating systems. Natural sciences are going towards exactly such a view of the problem. Therefore, as Piątek (2007) rightly observes, "healthy ecosystems ... owing to natural homeostatic systems, regulating the circulation of matter and energy ... stay in the state of permanent, sustainable development. If they become unbalanced, they are able to return to the balance as long as they have a sufficient level of biodiversity. Natural ecosystems do not need awareness to react to changes in the environment in a sustainable manner.' Also, a human being is not an alienated creature but one living together with the environment of which he is a part and that he changes at the same time. In this aspect, a problem occurs concerning the geographical and time dimension of the reflection over the use of the existing resources of the Earth by man. The geographical dimension refers to the internationalisation and globalisation processes that make the level of co-dependence among different locations as related to the exploitation 
and use of natural resources increase rapidly. The time dimension concerns the progressing intensification of economic activity related to the intensification of the problem of the scarcity of resources and, as a consequence, an inter- and intra-generational balance and justice in the use of those resources (Nilsson, Griggs, \& Visbeck, 2016). Considering mankind as a whole, a dilemma occurs concerning the availability of resources that should be shared - both by the present and future generations. The problem of shared resources discussed in the deliberations by Lloyd (the metaphor of a pasture and its use by shepherds increasing their herds whose actions that are seemingly effective in the short-term result in limitations and a lack of effectiveness for other users and for themselves in the long-term) and then developed by Hardin (see Walker, 2009 and Ostrom, 2015) highlights the need for the real activation of activities with regard to natural resource management (that is, the globe). This need must, however, be fulfilled in the multi-generational dimension; thus, it requires the use of resources in such a way as to optimise the relative effects but from the point of view of the wealth of future generations as well and not only of the present generation. Such a view of the issue of using natural resources is nothing new. However, in spite of announcing as early as 1987 (under the auspices of the UN of the socalled Gro Harlem Brundtland Report), the problem is not solved, but increasing imbalances in the natural, social, and economic capital occurring as a whole (Borowiecki \& SiutaTokarska, 2018) are still an issue to be resolved. Therefore, a question arises:

Why, despite the good will of the representatives of the governments of the world's countries and international institutions (UN), does mankind still keep going downhill, not implementing tasks arising from the concept of sustainable and permanent development that was defined more than 30 years ago?

It seems that this state of affairs is caused by a misunderstanding and lack of the actual implementation of 'values' in socio-economic life superior to the natural world but being the sine qua non condition for the existence of life as such.

\section{The Term of Value and Sustainable Development in the Aspect of the Functioning of Enterprises}

In the philosophical approach, value is the basic axiological category standing for everything that is valuable and desirable and what constitutes the ultimate goal of humans. Value can be understood and determined both in reference to the object itself as well as its qualities and the idea (Hartman, 2011).

The term value itself (Latin: valor) comes from the term 'be valuable' derived from philosophy and being the object of axiological research; that is, studies about values (Biddle \& Schafft, 2015). As a philosophical discipline, axiology in particular includes studies on:

- the essence of value (valor as the major quality of any value and as an idea),

- types of values (biological, aesthetic, scientific, ethical, absolute, and relative values),

- conditions of the cognition and realisation of values,

- structure and the manner of the existence of a value,

- hierarchy and volume of a value,

- autonomy and objectivity of values ${ }^{4}$.

\footnotetext{
${ }^{4}$ The broad sense of value as a philosophical category was presented by outstanding Polish philosopher Ingarden, among others.
} 
There is an ongoing dispute among philosophers concerning the understanding of value with regard to objects in the objective or subjective approach (Biedenbach, 2016). Objectivists approach value as a quality inherent to the entity/phenomenon irrespective of a subjective assessment made by a specific entity in accordance with a given point of view, whereas subjectivists understand it as a quality assigned to an object/phenomenon by an entity, revealing only specific emotional and volitional attitudes ${ }^{5}$ with regard to the evaluation. According to contemporary philosophy, a kind of a compromise assumes that values stand for the attitude of the acting individual to a given object, which is related to the belief that the object directly or indirectly fulfills his needs; it is subjective in this approach, but it has an objective aspect at the same time since value depends on the potential properties of a given object.

As can be observed, 'value' means the property of an object or an object possessing this property 6 - only a positive property or a positive or negative property; the property has either a special economic significance or a broad philosophical one. An important aspect of the indicated understanding of the notion of value is distinguishing two types of value - this desired one (namely, the positive value) but, at the same time, one that can be defined as a negative pejorative one (which is defined as an anti-value ${ }^{7}$ ). In the literature of the subject, we can also indicate the isolation of values felt, declared, and recognized. Considering the systematic division, Ingarden indicates their three groups: vital, cultural, and moral values (Gabrusewicz \& Przybylska-Kapuścińska, 2013).

On the other hand, by taking into account the aspect of experience, one can notice a transition of the civilization of the turn of the 20th and 21st century into the so-called 'liquid modernity' (Bauman, 2000), the core of which is the lack of rooting (identity, values) and the absence of real borders (geopolitical $\rightarrow$ communication $\rightarrow$ trade $\rightarrow$ consumption). Hence, the notion of liquid modernity may be characterised by variability, relativity, and pluralism, all of which 'deprive practically every single being of its value.'

Assuming that values escape their descriptive definition, what should be indicated is the understanding of values as a specific pattern that requires realization in human action. In a similar way, we should look at the problem of sustainable development in the context of the three capitals included in it (namely natural, social, and economic ones) as a concept requiring a new philosophy of a deed and the deed itself.

As it is correctly emphasized by Piątek (2007), philosophy 'wants to establish the human world, seeing the specificity of a human in his symbiosis with nature, and not in the opposites occurring between them.' Therefore, it is related to the understanding that mankind is rooted in nature with pressure put on biocentrism as a new model of man's attitude towards nature with the simultaneous opposition to the attitude of arrogant anthropocentrism (Piątek, 2007).

The realisation of the sustainable development concept requires an attitude towards the process of its implementation (Siva, Gremyr, Bergquist, Garvare, Zobel, \& Isaksson, 2016) that will be consistent and at the same time filled with the power of idea and can, moreover, be indicated itself as a value for which the mankind of the 21st century strives

\footnotetext{
${ }^{5}$ Volitional - that is, dependent on the will.

${ }^{6}$ In this context, Tischner uses the definition 'the object that is entitled to any values' (see Tischner, 2002).

${ }^{7}$ On the grounds of axiology, assigning a specific sign to a value refers to perceiving it from the perspective of existential judgments.
} 
(as opposed to the ubiquitous liquid modernity). In this aspect, the notion of value is an integral part of the concept of sustainable development, creating a value by the fact of its existence as an idea in this concept.

Philosophical considerations pertaining to the essence and conditions of shaping values were an important starting point for the formation and development of the economic value theory. The basis for the development of the economic value theory were the works by Smith (2007), Ricardo (2001), and Say (2001), who defined and conceptualised such basic concepts as exchangeable value, value in use, natural value, and reproductive value. This created the basis for the further development of the theory of value and its use as related to the processes of the functioning and development of enterprises. A business's understanding of value is based on the concept of economic value related to the ability of economic resources to generate economic benefits resulting from their effective use, leading to the multiplication of value of the invested capital (Mayfield, 1997). In this context, value and its creation can be considered in the enterprise's operations from three perspectives:

- from the management perspective, where the maximisation of market value as the enterprise's goal and the purpose of corporate governance and the basis for assessing its effectiveness are of key importance,

- from the perspective of accounting, which is a system for measuring economic values characterising the activities of the enterprise and the value of its assets, equity, and liabilities,

- from the business valuation perspective, where the concept of asset-based value and the concept of income-based value are the basis of the enterprise's valuation methods as well as the value and valuation standards.

It should be stressed that the concept is multidimensional and at the same time dynamic, which brings specific consequences in its implementation, including the problems and dilemmas occurring and concerning measures as well as defining the value of such measurements itself (Palea, 2018; Hak, Janoušková, \& Moldan, 2016).

What results from the research conducted by the Center for Business Excellence in the Farmer School of Business at Miami University and Crowe Horwath LLP is that the majority of business leaders are convinced of the strategic value for the organisation on account of sustainable development initiatives. However, what is challenging to them is data reporting, as there are no unanimously defined methods of their measurement.

One of the possibilities used by businesses to report their activity is preparing such reports based on the guidelines of the International Integrated Reporting Council (IIRC) as well as the indicators of the Global Reporting Initiative (GRI). The indicators proposed by the GRI are divided into the following segments (Szejnwald-Brown, de Jong, \& Levy, 2008; Tarquinio, Raucci, \& Benedetti, 2018):

- strategy and analysis,

- profile of the organisation,

- identification of significant aspects and scopes,

- engagement of stakeholders,

- profile of the report,

- supervision,

- corporate governance,

- ethics, 
- detailed indicators, including the following:

o information concerning attitude towards management,

o economic indicators, including economic results, presence on the market, indirect economic influence, and buying practices,

o environmental indicators, including materials/raw materials, energy, water, biodiversity, emissions, sewage and waste, products and services, compliance with regulations, transport, general, assessment of the supplier's environment, and complaint mechanisms concerning environmental issues,

o social indicators, including hiring practice and dignified work, human rights, society, and responsibility for the product.

Applied business practices should contribute to the growth of the value of a given business entity (influence on economic capital) and support the fulfillment of the needs occurring with regard to natural and social capitals (see also Ikemefuna, 2016). An increase in the value of a business entity is therefore discussed in activities that can be presented by means of three key factors of sustainable development on the firm's level while setting its environmental, social, and economic goals at the same time (Moldavska \& Welo, 2019; Dhahri \& Omri, 2018):

1. The ecological (environmental) factor, which first strives to minimise the negative impact of the company's activities on the environment and natural resources and then affect a positive influence (initiatives and activities restoring the natural state of the environment).

2. The social factor, which is manifested through a positive influence on society's cooperation with both the employees and the local community. It should be done by creating or taking part in social programmes of this type as well as launching initiatives for pro-social activities, such as raising the awareness of human rights and workers' rights, as well as propagating ethical activities and responsibility for the products/services sold.

3. The technical and economic factors, whose main assumption is increasing the safety of the entity's employees while maintaining the simultaneous growth of the economic effectiveness of the enterprise related to the application of modern pro-environmental technologies.

An important issue in the context of reporting the accomplishment level of sustainable development by enterprises is the problem of the implementation (Moratis \& Melissen, 2019) of this type of activity' practically exclusively in large and very large economic entities, with the omission of the SME-sector enterprises (Lortie, Nadeau, \& Vezeau, 2016), whose number in the world economy is the largest in terms of quantity. Therefore, the need for these types of activities in smaller entities is indicated as well, with the consideration to the specificity of their activity and size class. In the opinion of the authors of this publication, the implementation of the sustainable development concept should have a bottom-up character (regardless of the top-down activities on the part of the state), starting from the smallest market participants up to the largest ones. Only the full awareness and sensitisation to this issue of all of the participants of this process can bring the expected changes. 
As Gabrusewicz and Przybylska-Kapuścińska observed (2013), the following can be indicated among the fundamental problems related to business reporting on the Sustainable Development Goals achievement:

- a lack of the systematisation of terms in sustainable development,

- a lack of capital resources that could support the development of this concept in enterprises,

- a lack of the existence of the standard process of the verification of costs and profits that come from the concept of sustainable development in the enterprise (value measurement).

Regardless of the discussed problems concerning the practical implementation of the concept of sustainable development in enterprises, it should be strongly emphasised that, on the level of enterprises 'the world' is quite often perceived from the perspective of an instrumental value. Such perceptions are then contradictory to authentic responsibility for the business activity of the organisation, as well as for the sustainable development of the enterprise. Hence, what is needed is a new rebuilt imperative of value creation that stands in opposition to the liquid modernity of the contemporary world while at the same time being rooted in the fundamental rule of the restitution of the idea of responsibility for

1. nature capital (as the sine qua non condition of the existence of life in general),

2. social capital,

3. economic capital,

according to the above-suggested rank.

\section{Imperative of Value Creation versus Models of Functioning of Enterprises}

The contemporary finance theory and firm theory regard the maximisation of the market value as the basic goal of a company activity. It is primarily the consequence of the logic on the basis of which the market economy functions as well as a resultant natural attempt of the capital owners to multiply its value. This corresponds to the assumptions of the financial (investment) perception of an enterprise as a form of investment; therefore, the natural aim of its activity is the growth of its market value (McTaggart, Kontes, \& Mankins, 1994). At the same time, the impact of various internal and external factors (including the establishment and evolution of legal forms as well as the types of ownership of enterprises) has brought about deep transformations in the models of the functioning of enterprises.

In the neoclassical model of an enterprise, the attention was concentrated on profit maximisation as the superior goal of its activity, which determined the corporate value in a fundamental way. The model was adequate for the époque of the capitalism of entrepreneurs - owners managing enterprises, who were obviously guided by their pragmatic expectations of the multiplication of the invested capital value while undertaking their managerial activities. The evolution of the types of enterprise ownership that were initiated with the separation of ownership from management and the emergence of non-classical private ownership shaped new enterprise models. These models are related to the following stages of economic development:

- the managerial capitalism era, where managerial decisions were handed over to managers employed for this and natural persons still prevailed in the ownership structures of enterprises. The occurrence of managers as a new group of company stakeholders 
arose primarily from the growing complexity of managerial decisions and, therefore, the need for the professionalisation of management,

- the investor capitalism era, which in addition to the separation of ownership and management is characterised by domination of the ownership structures of enterprises by institutional investors, including investment funds, pension funds, insurance funds, and banks; thus, entities in the case of which pressure on the multiplication of the invested capital value arises from the necessity to fulfill the expectations of the customers of the mentioned financial institutions.

The indicated transformations in the models of the functioning of enterprises caused the necessity of a significantly different approach, both to the issue of defining the basic enterprise's aim and the ways of ensuring its effective and efficient realisation. Under these conditions, the pro-value paradigm of management and the relative value-based management concept were formed and developed.

The pioneer contribution to the creation, development, and dissemination of valuebased management was primarily made by the following authors:

- in the field of the identification of the premises and assumptions to create the concept: Rappaport (1986),

- in the field of conceptualisation value-based management as a new management concept: Copeland, Koller, and Murrin (1990), McTaggart, Kontes, and Mankis (1994),

- in the field of creating and developing tools for measuring and evaluating the effectiveness of value creation: Steward (1991) and Ehrbar (1998).

During the following years, we continued to find a creative continuation of the abovementioned authors' achievements in the field of value-based management concept development in the works of Black, Wright, and Bachman (1998), Knight (1998), Martin and Petty (2000), and Young and O'Byrne (2001).

The concept of value-based management binds corporate strategy with the process of managing company finance along with their orientation to making decisions resulting in the maximisation of corporate value. This was supposed to contribute to the integration of the goals of the owners with those of the managers and, thus, to the liquidation of the negative effects that the separation of ownership and management brought for the multiplication of corporate value. At the same time, it set another stage in management science related to its growing financialisation and, thus, the departure from the technocratic approach formed by the authors of this scientific discipline. Financialisation is connected with an increasing role of financial institutions in the processes of managing an enterprise of the non-financial sector, as well as with the growing significance of the capital market as a mechanism of exercising control over an enterprise, among others (Stochhammer, 2013).

Changes within the enterprise functioning models also arose from other parallelly occurring transformations in their ownership structures and relative management mechanisms. This mainly refers to the following:

- the inclusion of state and local government units in the ownership structures of enterprises, which contributed to the emergence of such ownership types as state ownership and communal ownership. At the same time, it brought about changes in the hierarchy of corporate goals related to the exposure of tangible goals connected with the accom- 
plishment of important interests of the state and local communities as company stakeholders. It simultaneously required the assurance of the effective allocation of public funds engaged in enterprises in the form of investment capital and subsidies, primarily enabling the accomplishment of important social goals,

- inclusion of employees in the ownership structures of enterprises, the result of which are subsequent types of ownership: employee ownership (based on American Employee Stock Ownership Plans),

- private and local governmental ownership focused on the consideration of coincidentally treated tangible, social, and financial goals.

At the same time, these transformations set the subsequent stages of economic development; namely, state and local government capitalism as well as stakeholder capitalism. These stages are related to the growing influence of increasingly broader groups of internal and external stakeholders on the functioning of the enterprise.

\section{A Need for Changes in the Concept of Value-Based Management}

The experiences derived from the practice of implementing the value-based management concept in the 1990s and at the beginning of the 21st century also showed the weaknesses of this concept as well as the potential threats that may result from it for the effectiveness of corporate value creation. A broad discussion on this referred primarily to the following:

- understanding the essence and mechanism of the concept functioning and the method of using partial and summary measures of corporate value creation within it (Smith, 2009),

- complexity and conditionings of the concept implementation (Starowic, Cooper, \& Davis, 2004).

The need for a deeper penetration of weaknesses of the value-based management concept was exposed by the latest economic crisis. The experiences derived from that crisis stressed the need for the introduction of significant changes in the area of the concept's use, referring mainly to the problem related to the measurement of the effectiveness of corporate value creation and the influence of the mechanism of corporate governance.

The essence of the value-based management concept makes the measurement of the effectiveness of corporate value creation play a crucial role from the point of view of the concept's fulfillment of the expectations formulated towards it. As a new group of enterprise effectiveness measures, market measures were intended to enable both the measurement of the partial effects of corporate value creation as well as create conditions to show the influence of these effects on this value. However, the lack of established patterns and standards referring to the selection and use of these measures also enabled the creation of an untrue image of the enterprise and its financial condition as a result of data manipulation and the use of gaps in accounting principles - including the methods of measuring the economic volumes that characterise the activity of an enterprise (Reichmann, 2016). At the same time, it has brought about numerous dysfunctions in the business value measurement we often deal with in the contemporary economy 'contaminated' by the phenomenon of excessive financialisation manifested in the detachment of financial flows from real processes (Stockhammer, 2013). It has also contributed to the growth of the phenomenon of asymmetry of information among management boards of enterprises and their owners and investors as well as credit institutions. This creates the 
need for a significant reorientation of our accounting paradigms. It should tend toward the development of patterns and standards adjusted to the changed reality and relative new information needs and, at the same time, create mechanisms protecting us from the negative consequences of creative accounting.

The global economic crisis also proved the inefficiency and ineffectiveness of many supervisory and regulatory mechanisms that should accompany the value-based management concept and constitute an integral component of corporate governance. An important premise for the creation and conceptualisation of value-based management was the need for a search for tools integrating the goals of the owners with the goals of mangers in charge of enterprises, which under the conditions of the separation of ownership and management brings a number of negative consequences for the effectiveness of corporate value creation (defined as an 'agency problem'). At the same time, the agency theory of enterprise is widely used as a perspective of describing the essence and mechanisms of corporate governance, which implies the need for linking the issues of the effectiveness of corporate value creation to the problem of corporate governance (Cornelius \& Kogut, 2003). Corporate governance mechanisms (and the ownership supervision within it) should prevent a situation when the blind faith of investors in unlimited possibilities to obtain higher and higher return rates becomes a factor stimulating the phenomenon of the detachment of the corporate value category from its fundamental bases and favors excessive behaviourism in its assessment, which may lead to tremendous perturbations in the functioning of the financial market. The mechanisms should also limit the voluntarism of managers, which is deprived of any rational premises (since managers undertook unjustifiable risks expecting higher and higher profits).

\section{New Imperative of Value Creation and the Concept of Sustainable Value-Based Management: In Search of Economic Reason and Moderation}

The global investor capitalism era and the experience derived from the consequences of the economic crisis at the beginning of the 21st century brought about the necessity of changes in respect to understanding and the way of using the value-based management concept. In this context, Porter and Kramer (2011) called for the need to redefine the basic goal of the enterprise, which they defined as creating shared value. The shared value concept exposes a wide group of internal and external stakeholders of a company as beneficiaries of the effects of creating its value. At the same time, it should be noted that, although originally oriented to multiplying the wealth of shareholders, the concept of value-based management is exhibited by the fact that the objectives of shareholders must be done at the expense of its depletion for the other stakeholders. On the contrary, the financial success of owners also creates conditions for an increase in value for other groups. Effective enterprises create new jobs and financial incentives for employees, pay higher taxes, and are reliable and desirable clients for banks and contractors for cooperators. At the same time, such an assertion suggests that enterprises create value for their owners only when value is created for other stakeholders at the same time. Therefore, the theory of stakeholders equates the goal of the company's activity in the first place with the creation of values for its internal and external stakeholders, noticing the broad social context of the functioning of business entities.

Taking into consideration the postulates of the concept of sustainable development and the benefits it brought from the point of view of the efficiency and sustainability of 
enterprise development, it seems logical to use these achievements for the needs of formulating a new imperative of corporate value creation and the postulate of the evolution of the value-based management concept towards sustainable value-based management. At the same time, the concept is the manifestation of the coincidence of the value-based management concept with the sustainable development concept and corporate social responsibility concept (Martin, Petty, \& Wallace, 2009). A hybrid character of the mentioned management concept is the reason for which its ideological foundation links the pro-value paradigm to the sustainable development and management ethics paradigms. The concept reflects a new approach to management, where the achievement of social goals is closely related to the achievement of economic goals and social responsibility coexists with responsibility towards the enterprise (Igwe, Icha-Huma, \& Madichie, 2018). Therefore, such an approach refers to the foundations of the corporate governance theory, referring to two models of the enterprise (the financial and social ones) and exposing varied beneficiaries of the effects of corporate value creation (Cornelius \& Kogut, 2003).

The concept of sustainable value-based management orients the enterprise's management system to attempt to maximise its market value while maintaining economic reason and moderation. The mentioned features relate primarily to such groups of stakeholders as owners and managers. As investors, the former should possess moderation in the formulation of the expectations related to the rate of capital multiplication - the required rate of return. Making key decisions affecting the use of capital, the latter should take a reasonable risk in the sense of responsibility for the long-term development of the enterprise and business continuity.

On this occasion, we can also see a return to the roots of the value-based management concept. Initially, the value-based management term referred to a management system focused on the provision of value for a broad group of company stakeholders (particularly the owners, employees and customers) being guided by the basic principles of economic and social justice. However, broad dissemination of the mentioned term in the circles of American business was the reason why it has only been associated with and used in the context of the multiplication of the enterprise market value and the wealth of its owners since the end of the 1980s. Its primary meaning was then replaced by the term 'justice-based management' as a management concept based on the idea of economic and social justice (Miller, Greaney, \& Brohawn, 1994).

\section{CONCLUSIONS}

The concept of value-based management was formed as a result of the evolution of provalue management due to changes in the internal and external conditionings of the enterprise functioning and experiences derived from the latest global economic crisis. It also positively responds to the formulated postulate of linking the issues of the effectiveness of corporate value creation to the problems of corporate governance through the examination of the corporate value creation process in a broad perspective of shared value creation whose beneficiaries are its various stakeholders. The proposed concept of sustainable value-based management is also inherent to the idea of the economics of moderation based on the creation of mechanisms for balancing economic streams and resources to maintain a dynamic balance, guaranteeing stable long-term economic growth (Kolodko, 
2017). Referring the assumptions and postulates of the economics of moderation to effective corporate value creation, we must say that investors should keep their own common economic sense in formulating expectations referring to the speed of the capital multiplication value, and managers should take risks within reasonable limits, not treating the value-based management concept as a financial perpetum mobile. This also leads to the conclusion that the reasonable profit concept referring to the assessment of the effectiveness of enterprises belonging to regulated sectors (Narmania, 2018) can also be the basis for the formulation of the postulate of a 'reasonable speed of corporate value creation.' Stakeholders of the enterprise (particularly its owners and managers as well as its potential investors) should perceive the process of multiplying the value of invested capital as a process of the sustainable creation of value in the long-term - without exposing the enterprise to excessive and unreasonable risk. Responsibility for the existence and sustainable development of an enterprise also requires a redefinition of the imperative of value creation, taking into account the necessity of sustainable use and multiplication of the enterprise's resources and not merely the blind pursuit of obtaining immediate benefits.

Taking into consideration the research subject concerning the problems of creating values in business organisations as well as the problems of sustainable development, some limitations connected with the above-mentioned issues have been displayed. These limitations appear due to the fact that the authors attempted to perceive the research area holistically; hence, the necessity for looking at it from the broadest possible perspective appears. The theoretical research in this respect concerned business organisations that are seen as a part of the economy sector; hence, making any generalisations from the conceptual digressions is extremely difficult. This difficulty results from the differences among organisations, such as their size classification (from micro to large entities), their range (from local to global markets), or their type of business activity (the service, industrial, or trade sectors). This means that the implementation of a new imperative of corporate value creation and the concept of sustainable value-based management (regardless of the general frame or base presented in the article) will require it to be filled with content that will, in turn, be fitted to the above-mentioned specific features of business organisations.

Further research should be led in the context of contemporary economic doctrines and the nature of 21st-century capitalism. Such research could reveal the possibilities of implementation of the idea of sustainable development, taking into account the need for the sustainability of this process in the long term.

\section{REFERENCES}

Bauman, Z. (2000). Liquid Modernity. Cambridge: Polity Press.

Bettencourt, L.M.A., \& Kaur, J. (2011). Evolution and structure of sustainability science. Proceedings of the National Academy of Sciences of the United States of America, 108(49), 19,540-19,545.

Biddle, C., \& Schafft, K.A. (2015). Axiology and Anomaly in the Practice of Mixed Methods Work Pragmatism, Valuation, and the Transformative Paradigm. Journal of Mixed Methods Research, 9(4), 320-334. https://doi.org/10.1177/1558689814533157

Biedenbach, T. (2016). The open secret of values: the roles of values in axiology in project research. Project Management Journal, 47(3), 139-155. https://doi.org/10.1177/875697281604700312

Black, A.P., Wright, P., \& Bachman, J.E. (1998). In Search of Shareholder Value: Managing the Drives of Performance. London: Pitman Publishing. 
Borowiecki, R., \& Siuta-Tokarska, B. (2018). Nauki o zarządzaniu w świetle paradygmatów. Przegląd Organizacji, 4, 7-15.

Borys, T. (2011). Zrównoważony rozwój - jak rozpoznać ład zintegrowany?. Problemy Ekorozwoju 6(2), 75-81.

Cairns, R.D., \& Martinet, V. (2014). An environmental-economic measure of_sustainable_development. European Economic Review, 69, 4-17. https://doi.org/10.1016/j.euroecorev.2014.03.001

Copeland, T., Koller, T., \& Murrin, J. (1990). Valuation: Measuring and Managing the Value of Companies. $1^{\text {st }}$ Edition, New York: John Wiley \& Sons Inc.

Cornelius, P., \& Kogut, B.M. (2003). Corporate Governance and Capital Flows in a Global Economy. New York: Oxford University Press.

Dahl, A.L. (2012). Achievements and gaps in indicators for sustainability. Ecological Indicators, 17, 14-19. https://doi.org/10.1016/j.ecolind.2011.04.032

Dobrescu, M., Hristache, D., \& lacob, S. (2012). Recent theoretical progress in economics and its impact on economic policy. Procedia - Social and Behavioral Sciences, 62, 562-565.

Dhahri, S., \& Omri, A. (2018). Entrepreneurship contribution to the three pillars of_sustainable_development: What does the evidence really say?. World Development, 106, 64-77. https://doi.org/10.1016/j.worlddev.2018.01.008

Egelston, A.E. (2013). Sustainable Development. A History. New York-London: Springer.

Ehrbar, A. (1998). EVA - The Real Key to Creating Wealth. New York: John Wiley \& Sons Inc.

Ellerman, D. (2004). Revisiting Hirschman on Development Assistance and Unbalanced Growth. Eastern Economic Journal, 30(2), 311-331.

Gabrusewicz, T., \& Przybylska-Kapuścińska, W. (2013). Wartość w zrównoważonym rozwoju. Nauki o Finansach, 4(17), 55-62.

Gray, R.H. (2006). Social, environmental and sustainability reporting and organisational value creation: Whose value? Whose creation?. Accounting, Auditing \& Accountability Journal, 19(6), 793819. https://doi.org/10.1108/09513570610709872

Hak, T., Janoušková, S., \& Moldan, B. (2016). Sustainable development goals: a need for relevant indicators. Ecological Indicators, 60, 565-573. https://doi.org/10.1016/j.ecolind.2015.08.003

Hartman, R.S. (2011). The structure of value: Foundations of Scientific axiology. Eugene: Wipf and Stock Publishers.

Hopwood, B., Mellor, M., \& O'Brien, G. (2005). Sustainable development: mapping different approaches. Sustainable Development, 13, 38-52.

Igwe, P.A., Icha-Ituma, A., \& Madichie, N.O. (2018). An Evaluation of CSR and Social Value Practices Among UK Commercial and Social Enterprises. Entrepreneurial Business and Economics Review, 6(1), 37-52, https://doi.org/10.15678/EBER.2018.060102

Ikemefuna, A. (2016). International Entrepreneurship Theory: Past, Present and Way Forward, Entrepreneurial Business and Economics Review 4(4), 93-103, https://doi.org/10.15678/EBER.2016.040406

Kattel, R., Kregel, J.A., \& Reinert, E.S. (2009). The Relevance of Ragnar Nurkse and Classical Development Economics. Working Papers in Technology Governance and Economic Dynamics, 21, 1-34.

Knight, J.A. (1998). Value Based Management: Developing a Systematic Approach to Creating Shareholder Value. New York: McGraw-Hill.

Kolodko, G.W. (2017). New Pragmatism: In the Quest for Economics and Development Policy in the 21th Century. Journal of Management and Business Administration. Central Europe, 25(2), 2-5. https://doi.org/10.7206/jmba.ce.2450-7814.192 
Kreickemeier, U., \& Wrona, J. (2017). Industrialisation and the Big Push in a Global Economy. Düsseldorf Institute for Competition Economics. Discussion Paper, 249, 1-25.

Lortie, M., Nadeau, S., \& Vezeau, S. (2016). Holistic sustainable_development: Floor-layers and microenterprises. Applied Ergonomics, 57, 8-16. https://doi.org/10.1016/j.apergo.2016.01.017

Martin, J.D., \& Petty, J.W. (2000). Value Based Management: The Corporate Response to the Shareholder Revolution. Boston: Harvard Business School Press.

Martin, J.D., Petty, J.W., \& Wallace, J.S. (2009). Value Based Management with Corporate Social Responsibility. New York: Oxford University Press.

Mayfield, J. (1997). Economic Value Management. The Route to Shareholder Value. Management Accounting, 75(8), 32-33.

McTaggart, J.M., Kontes, P.W., \& Mankins, M.C. (1994). The Value Imperative. Managing for Superior Shareholder Returns. New York: The Free Press.

Miller, J.H., Greaney, M.D., \& Brohawn, D.K. (Eds.) (1994). Curing World Poverty: The Role of Property. New York: Social Justice Review.

Moldavska, A., \& Welo, T. (2019). A Holistic approach to corporate_sustainability assessment: Incorporating_sustainable_development goals into sustainable manufacturing performance evaluation. Journal of Manufacturing Systems, 50, 53-68. https://doi.org/10.1016/j.jmsy.2018.11.004

Moratis, L., \& Melissen, F. (2019). How do the sustainable_development goals question rather than inform corporate sustainability?. Resources, Conservation and Recycling, 141, 253-254.

Narmania, D. (2018). Economic Policy Uncertainty and Risk Management in Regulated Sectors. International Journal of Business and General Management, 7(4), 19-28.

Nilsson, M., Griggs, D., \& Visbeck, M. (2016). Policy: map the interactions between Sustainable Development Goals. Nature, 534, 320-322. https://doi.org/10.1038/534320a

Olawumi, T.O., \& Chan, D.W.M. (2018). A scientrometric review of global research on sustainability and sustainable development. Journal of Cleaner Production, 183, 231-250. https://doi.org/10.1016/j.jclepro.2018.02.162

Ostrom, E. (2015). Governing the commons. The evolution of institutions for collective action. Cambridge: Cambridge University Press.

Palea, V. (2018). Financial reporting for_sustainable development: Critical insights into IFRS implementation in the European Union. Accounting Forum, 42(3), 248-260. https://doi.org/10.1016/j.accfor.2018.08.001

Piątek, Z. (2007). Przyrodnicze i społeczno-historyczne warunki równoważenia ładu ludzkiego świata. Problemy Ekorozwoju, 2(2), 5-18.

Porter, M.E., \& Kramer, M.R. (2001). The Big Idea: Creating Shared Value. Harvard Business Review, 1, 62-77.

Pulgarín, A., Eklund, P., Garrote, R., \& Escalona-Fernández, M.I. (2015). Evolution and Structure of Sustainable Development: A Bibliometric Study. Brazilian Journal of Information Scienc, 9(1).

Rappaport, A. (1986). Creating Shareholder Value. The New Standard for Business Performance. New York: The Free Press.

Reichmann, M. (2016). Creative Accounting and Electoral Motives: Evidence from OECD Countries. Journal of Comparative Economics, 44(2), 243-257. https://doi.org/10.1016/j.jce.2015.07.001

Ricardo, D. (2001). On The Principles of Political Economy and Taxation. Ontario: Batoche Books, Kitchner.

Say, J.B. (2001). A Treatise on Political Economy; or the Production, Distribution, and Consumption of Wealth. Ontario: Batoche Books, Kitchner. 
Sinakou, E., Boeve-de Pauw, J., Goossens, M., \& Van Petegem, P. (2018). Academics in the Field of Education for Sustainable Development: Their Conceptions of Sustainable Development. Journal of Cleaner Production, 184, 321-332.

Siva, V., Gremyr, I., Bergquist, B., Garvare, R., Zobel, T., \& Isaksson, R. (2016). The support of Quality Management to sustainable development: a literature review. Journal of Cleaner Production, 138(2), 148-157.

Smith, A. (2007). An Inquiry into the Nature and Causes of the Wealth of Nations. Amsterdam - Lausanne - Melbourne - Milan - New York - Sao Paulo: MetaLibri.

Smith, P. (2009). Shareholder Value Implementation: Turning Promise into Reality, L.E.K. Consulting Executive Insights, IV(1), 1-7.

Solivetti, L.M. (2005). W.W. Rostow and His Contribution to Development Studies: A Note. The Journal of Development Studies, 41(4), 719-724. https://doi.org/10.1080/00220380500092903

Starovic, D., Cooper, S., \& Davis, M. (2004). Maximising Shareholder Value. Achieving clarity in decision-making. London: CIMA.

Steward, III, G.B. (1991). The Quest for Value. A Guide for Senior Managers. New York: Harper Business.

Stockhammer, E. (2013). Financialization and the Global Economy. In M.H. Wolfson \& G.H. Epstein, (Eds.), The Political Economy of Financial Crises. New York: Oxford University Press.

Szejnwald-Brown, H., de Jong, M., \& Levy, D.L. (2008). Building institutions based on information disclosure: lessons from GRI's sustainability reporting. Journal of Cleaner Production, 17, 571580. https://doi.org/10.1016/j.jclepro.2008.12.009

Tarquinio, S., Raucci, D., \& Benedetti, R. (2018). An Investigation of Global Reporting Initiative Performance Indicators in Corporate Sustainability Reports: Greek, Italian and Spanish Evidence. Sustanaibility, 10, 1-19.

Tischner, J. (2002). Thinking in Value., Cracow: Polish Publishing House 'Znak.'

Walker, P.A. (2009). From 'tragedy' to commons: How Hardin's mistake might save the world. Journal of Natural Resources Policy Research, 1(3), 283-286. https://doi.org/10.1080/19390450903040520

Wang, X., \& Piesse, J. (2009). Economic Development and Surplus Labour: A Critical Review of the Lewis Model. BWPI Working Paper, 89, 1-32.

Young, S.D., \& O'Byrne, S.F. (2001). EVA and Value-Based Management. A Practical Guide to Implementation. New York: McGraw-Hill. 


\section{Authors}

The contribution share of authors is equal and amounted to $50 \%$ each of them.

\section{Andrzej Jaki}

Associate Professor at Department of Economics and Organization of Enterprises, Cracow University of Economics, His research interests are in value-based management and business valuation. Correspondence to: prof. UEK dr hab. Andrzej Jaki, Cracow University of Economics, Department of Economics and Organization of Enterprises, ul. Rakowicka 27, 31-510 Kraków, Poland; +48 1229353 30; andrzej.jaki@uek.krakow.pl

ORCID (ㄷ) http://orcid.org/0000-0002-4799-4343

\section{Barbara Siuta-Tokarska}

Associate Professor at Department of Economics and Organization of Enterprises, Cracow University of Economics, Her research interest include enterprise development, especially SMEs; sustainable development; development management.

Correspondence to: prof. UEK dr hab. Barbara Siuta-Tokarska, Cracow University of Economics, Department of Economics and Organization of Enterprises, ul. Rakowicka 27, 31-510 Kraków, Poland, +48 1229374 37, siutab@uek.krakow.pl

ORCID (ㄱ) http://orcid.org/0000-0001-9078-6243

\section{Acknowledgements and Financial Disclosure}

The paper was financed with subsidies granted to the Faculty of Management of the Cracow University of Economics for maintaining the research capacity.

This article has been presented as the academic paper at the scientific conference GLOB2018: "Globalization and Regionalization in the Contemporary World: Competitiveness, Development, Sustainability" organized in Kraków on 21-22 September 2019.

\section{Copyright and License}

This article is published under the terms of the Creative Commons

Attribution - NoDerivs (CC BY-ND 4.0) License http://creativecommons.org/licenses/by-nd/4.0/

Published by the Centre for Strategic and International Entrepreneurship - Krakow, Poland

Ministry of Science and Higher Education Republic of Poland
The copyediting and proofreading of articles in English is financed in the framework of contract No. 913/P-DUN/2019 by the Ministry of Science and Higher Education of the Republic of Poland committed to activities aimed at science promotion.

This publication has been co-financed by the European Commission Representation in Poland. The European Commission, or any person acting on its behalf, is not responsible for the use of the information contained in this publication. This publication reflects the views only of the authors, and the European Commission cannot be held responsible for any use which may be made of the information contained therein. 
